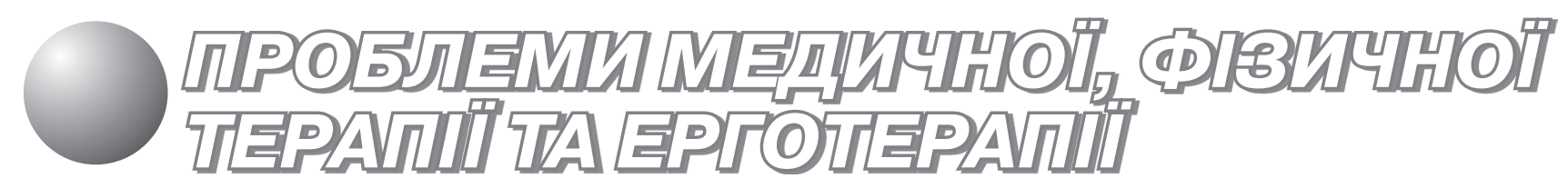

DOI: https://doi.org/10.32652/spmed.2020.2.62-72

\section{Фізична терапія пацієнтів після кардіохірургічних втручань: аналіз опитувань фізичних терапевтів різних країн}

\author{
Удк 616.12-039-089.8:615.825 \\ В. В. Вітомський, Х. М. Аль-Хавамдех, \\ О. Б. Лазарєва, М. В. Вітомська
}

Національний університет фізичного виховання і спорту України, Київ, Україна

Резюме. Мета. Проаналізувати результати опитувань фізичних терапевтів різних країн щодо особливостей їх практики з кардіохірургічними пацієнтами. Методи. Аналіз та порівняння результатів досліджень, котрі присвячені вивченню особливостей фізичної терапії пацієнтів після кардіохірургічних втручань на стаціонарному етапі у формі опитувань фізичних терапевтів, а також аналіз обґрунтованості моделей фізичної терапії.

Результати. Отримано досить великі відмінності та різноманітні підходи до передопераційного консультування та навчання пацієнтів елементам фізичної терапії. Частота використання фізичної терапії для інтубованих пацієнтів також різнилася. Ключові особливості мобілізації пацієнтів та використання терапевтичних вправ відрізнялися у різних країнах. Кількість процедур також мала широкий діапазон. Вправи з глибоким диханням були однією з найпоширеніших технік серед респіраторної фізичної терапії. Запобіжні заходи після стернотомії та терміни їх дотримання не були однаковими. Наукова обґрунтованість практики фізичної терапії залишається сумнівною. Особистий досвід, протокол лікарні та уподобання колег, а не результати наукових досліджень, є основою практики. Впровадження результатів наукових досліджень у практику є складним процесом з рядом перешкод.

Висновки. Подальший аналіз та розробка міжнародних рекомендацій з науковим обґрунтуванням необхідні для встановлення оптимального протоколу фізичної терапії пацієнтів після хірургічних втручань на серці.

Ключові слова: серцева хірургія, терапевтичні вправи, легенева реабілітація, мобілізація, стернотомія.

Physical therapy of cardiac surgery patients: analysis of surveys of physical therapists in developed countries

V. V. Vitomskyi, K. M. Al-Hawamdeh, O.B. Lazarieva, M. V. Vitomska

National University of Physical Education and Sport of Ukraine, Kyiv, Ukraine

Abstract. Objective: to analyze the results of surveys of physical therapists in developed countries on the peculiarities of their practice with cardiac surgery patients.

Methods. This work is the result of analysis and comparison of research results, which are devoted to the study of the features of physical therapy after cardiac surgery at the inpatient stage in the form of surveys of physical therapists, as well as the analysis of the validity of models of physical therapy. Results. There are large differences and a variety of approaches to preoperative counseling and patient education. The frequency of physical therapy for intubated patients also varied. The key 
features of patient mobilization and the use of therapeutic exercises differed between countries. The number of sessions also had a wide range. Deep breathing exercises were one of the most common techniques among respiratory physical therapy. Precautions after sternotomy and timing were not the same. The scientific validity of the practice of physical therapy remains questionable. Personal experience, the hospital protocol, and the preferences of colleagues, rather than the results of research, were the basis of the practice. Putting research results into practice is a complex process with a number of obstacles.

Conclusion. Further analysis and development of international recommendations with scientific substantiation are necessary to establish the optimal protocol of physical therapy of patients after heart surgery.

Keywords: cardiac surgery, therapeutic exercises, pulmonary rehabilitation, mobilization, sternotomy.

Постановка проблеми. Фізична терапія (ФТ) часто призначається пацієнтам після кардіохірургічних втручань (КХВ) з метою профрілактики чи зменшення частоти, важкості ускладнень. Традиційно, ФТ впродовж перебування у лікарні включає ранню мобілізацію, терапевтичні та дихальні вправи. Користь і значення післяопераційної ФТ $\epsilon$ загальноприйнятим положенням у практиці, але досі залишаються невизначеними найбільш ефективні методики легеневої ФТ та терміни ранньої мобілізації. Літературні джерела пропонують дуже велике різноманіття у заходах та особливостях їх виконання. Водночас $€$ досить велика кількість досліджень, котрі не підтверджують ефективність певних технік респіраторної ФТ $[9,24,39]$ та протоколів ранньої мобілізації $[6,14,15]$.

3 огляду на це, питання відповідності практики та результатів наукових досліджень $€$ важливим. 3 метою його вирішення проводять опитування фрізичних терапевтів різних країн для оцінки їх практичної діяльності та її обгрунтування. Водночас, багато стратегій та різноманітних методів ФТ застосовують післяопераційно, і вони відрізняються між собою в різних країнах [35, 49]. Тому проведення аналізу та оцінка світової клінічної практики $\epsilon$ необхідним кроком для розвитку ФТ після кардіохірургічних втручань у нашій країні.

Очікується, що інформація, отримана в результаті нашого дослідження, допоможе фрізичним терапевтам в оцінці сучасних практик та у подальшому розвитку клінічних протоколів.

Зв'язок роботи 3 науковими планами $i$ темами. Роботу виконано згідно з планом НДР НУФВСУ на 2016-2020 рр. за темою: 4.2. «Організаційні та теоретико-методичні основи фрізичної реабілітації осіб різних нозологічних, професійних та вікових груп» (номер держреєстрації 0116U001609).

Мета дослідження - проаналізувати результати опитувань фрізичних терапевтів розвинутих країн щодо особливостей їх практики з кардіохірургічними пацієнтами.
Методи дослідження: аналіз та порівняння результатів досліджень, котрі присвячені вивченню особливостей ФТ після кардіохірургічних втручань на стаціонарному етапі у фоормі опитувань фрізичних терапевтів, а також аналіз обгрунтованості моделей ФТ.

Результати дослідження. У роботі B. Tucker зі співавт. [44] опитування проводили серед головних фрізичних терапевтів кардіохірургічних клінік Австралії та Нової Зеландії. Щодо оцінки організації процесу дослідники повідомили, що середня кількість фрізичних терапевтів хірургічного відділення становила 1,4 штатних працівника. Не було суттєвої різниці в рівні персоналу між державними та приватними лікарнями.

Кількість процедур лікування варіювала між лікарнями від одного до шести разів на день (медіана 1,7), а надавали процедури впродовж 2-9 (медіана 5,3) післяопераційних днів (ПОД). Послуги у вихідні дні регулярно надавали у $83 \%$ лікарень, і лише одна лікарня регулярно надавала послуги на ніч. Вечірні послуги надавала за потребою у $71 \%$ лікарень у будні дні та у 74 \% - у вихідні. Середня тривалість перебування в післяопераційному стаціонарі була значно більшою у приватних лікарнях (8-10 днів), ніж у державних (5-7 днів). У $89 \%$ опитувань усі пацієнти отримували ФТ, а з інших $11 \%-75 \%$ та $25 \%$ виключали пацієнтів на підставі неускладненого післяопераційного відновлення чи результатів передопераційної оцінки відповідно.

У цьому дослідженні $94 \%$ респондентів зазначили, що усі планові пацієнти, котрі госпіталізувалися для коронарного шунтування (КШ), оцінювалися фрізичним терапевтом. Основні характеристики оцінювання також представлені у роботі В. Tucker [44]. Специфрічний протокол оцінки фрізичним терапевтом та/або протокол лікування після екстубації мали 76 \% респондентів, але $19 \%$ використовували лише оцінювання пацієнта. 
У роботі В. Tucker зі співавт. [44] повідомляється про велику розбіжність у методиках та протоколах ФТ. Використовувані респондентами методи включали в себе вправи з глибоким диханням, специфічні вправи на розширення грудної клітки, маневри утримування на вдиху та стимулювальну спірометрію, техніки форсованого видиху та методики з позитивним тиском у дихальних шляхах, стимулювання кашлю та постукування, позиціонування (зокрема з боку на бік) та терапевтичні вправи (для кінцівок, тулуба та шиї, ходьбу сходами та звичайну). Зазначимо, що до виконання вправ з глибоким диханням, стимулювальної спірографрії, позиціювання, кашлю та ходьби коридором часто залучали медичну сестру. Дані про втручання для інтубованих пацієнтів були обмежені.

Щодо мобілізації пацієнтів, то Tucker B. [44] відзначив, що початок амбуляцій до третьої доби вказаний у $75 \%$ анкет, ходьба сходами на четвертий-п'ятий ПОД - у 83 \%. Найбільш впливовим фактором, що визначає вибір лікування, був особистий досвід. Однак аналіз наукових джерел також сприяв вибору. Крім того, $34 \%$ респондентів повідомили, що рекомендації щодо лікування післяопераційних пацієнтів відрізняються у різних хірургів їхньої лікарні. Для лікування ателектазів та видалення мокроти основним вибором респондентів було позиціонування, котре часто доповнювалося вправами 3 глибоким диханням.

Дослідження особливостей фрізичної терапії у клініках Швеції було проведено E. Westerdahl та M. Moller [49]. Усі фрізичні терапевти $(n=29)$ заявили, що вважають ФТ необхідною після КХВ; $55 \%$ вважали ФТ, котру надають, оптимальною, $31 \%$ - не оптимальною, а $14 \%$ - не мали впевненої відповіді. Велика кількість пацієнтів, брак ресурсів, нестача часу догляду та збільшення навантаження були основними причинами неоптимального початку процедур ФТ.

У цьому опитуванні [49] більшість (90\%) фрізичних терапевтів проводили передопераційну консультацію пацієнтів щодо ранньої мобілізації (90\%), обмежень після стернотомії (90\%), ризиків післяопераційних легеневих ускладнень (90 \%), методики мобільності у ліжку/кріслі (80 \%), дихальних вправ та техніки кашлю (80\%), вправ для кінцівок (69\%). Основним обгрунтуванням втручання після серцевої хірургії було запобігання та лікування післяопераційних ускладнень, поліпшення легеневої функції та сприяння руховій активності.

Усі, крім трьох з 29 респондентів, вказали [49], що фізичний терапевт у їх лікарнях авто- матично відвідував усіх пацієнтів після КХB, а інші три - за умови особливих потреб пацієнта. У будні фрізичні терапевти Швеції регулярно лікують пацієнтів у перший ПОД (90\% респондентів; 1-3 процедури), другий та третій ПОД (93 та $69 \%$; 1-2 процедури); у четвертий та п'ятий ПОД - у значно меншій кількості лікарень (28 \%; 1 процедура). Втручання ФТ ніколи не проводили вечорами. У суботи втручання регулярно проводили у перший ПОД за даними $59 \%$ респондентів, а за потреби - $41 \%$. Аналогічні показники становили відповідно 31 та 14 \% для неділі, тоді як $55 \%$ фозіотерапевтів ніколи не проводили лікування у неділю. На другий ПОД ФТ здійснювали у суботу регулярно $17 \%$ респондентів, а за потреби - 83 \%. Якщо другий ПОД припав на неділю - звичайна ФТ не проводилася, проте $48 \%$ респондентів відзначили ії можливість у разі потреби чи призначення лікаря.

Під час проведення ФТ у Швеції [49] регулярно оцінюють та фріксують рухливість, вставання 3 ліжка/стільця (100\%), амплітуду руху плечей та верхніх кінцівок (62 \%), грудної клітки (59\%), шийного і грудного відділи хребта (38 \%), а також активність повсякденного життя (21\%), толерантність до фрізичних навантажень (17\%).

Рутинне використання ранньої мобілізації та терапевтичні вправи були поширеними впродовж перших ПОД, але вибір вправ та тривалість лікування були різними серед фрізичних терапевтів Швеції [49]. Зокрема, виконання сидіння на краю ліжка чи на стільці під контролем фрізичного терапевта у перший ПОД відмітили $97 \%$ респондентів, а у другий та третій ПОД частота значно знизилася до 52 та 48 \% відповідно. Щодо виконання стояння під контролем фрізичного терапевта спостерігалася аналогічна тенденція впродовж перших трьох ПОД - 93, 55, 48 \%. Дещо іншими були показники для ходьби у палаті - 28, 79, $52 \%$ відповідно. Тенденція у виконанні ходьби у коридорі під контролем фрізичного терапевта мала такий вигляд - 28, 66, 93 \% відповідно до перших ПОД. Білатеральні вправи для верхніх кінцівок виконували 10,69 та $76 \%$ респондентів у перші три ПОД, а для нижніх кінцівок відповідно - 41, 31 та $28 \%$. Ходьбу сходами використовували рідше 21 та $38 \%$ у третій та четвертий ПОД, але загалом $79 \%$ респондентів використовували їі. Групові заняття забезпечували $62 \%$ фізичних терапевтів.

За даними 14 з 29 респондентів, письмові рекомендації або протоколи щодо ФТ втручання для екстубованих пацієнтів у відділенні інтенсивної терапії були доступні, тоді як інструкції щодо ФТ для інтубованих пацієнтів були менш доступними $(n=4)[50]$. 
ТАБЛИЦЯ 1 - Рекомендації пацієнтам щодо запобіжних заходів після стернотомії

\begin{tabular}{|l|c|c|}
\hline \multicolumn{1}{|c|}{ Заборона використовувати } & \multicolumn{2}{|c|}{ Відсоток респондентів } \\
\cline { 2 - 3 } & Швеція [49] & Греція [28] \\
\hline $\begin{array}{l}\text { Руки для відштовхування під } \\
\text { час зміни положення лежачи на } \\
\text { положення сидячи }\end{array}$ & 17 & 38 \\
\hline $\begin{array}{l}\text { Руки для відштовхування під } \\
\text { час зміни положення сидячи на } \\
\text { положення стоячи }\end{array}$ & 97 & 38 \\
\hline $\begin{array}{l}\text { М'язи живота для підняття тулуба } \\
\text { під час зміни положення лежачи на } \\
\text { положення сидячи }\end{array}$ & 41 & 16 \\
\hline $\begin{array}{l}\text { Руки та плечі у активному русі з } \\
\text { повною амплітудою }\end{array}$ & 3 & 22 \\
\hline $\begin{array}{l}\text { Руки та плечі у активному русі з } \\
\text { повною амплітудою з вагою 1-2 кг }\end{array}$ & 41 & 24 \\
\hline Ходунки з колесами & 3 & 42 \\
\hline Милиці & 66 & 49 \\
\hline
\end{tabular}

Усі опитані фрізичні терапевти Швеції [50] давали завдання пацієнтам регулярно виконувати дихальні вправи післяопераційно (найчастіше вправи з глибоким диханням - 62 \%, з використанням пристрої (маска, мундштук, пляшка 3 водою) з позитивним тиском на видиху (2-20 см $\left.\mathrm{H}_{2} \mathrm{O}\right)-83$ \%). Позиціювання на боці лежачи застосовувала приблизно 30 \% респондентів. Проте використання методик легеневої реабілітації значно знижувалося на третій та четвертий ПОД. Усі фрізіотерапевти Швеції, окрім одного, доручали пацієнтам виконувати рекомендовані техніки дихальних вправ раз на годину впродовж перших двох ПОД днів. Кількість вдихів для одного тренування значно варіювалась: $10 \times 3$ вдихи $(n=21), 20 \times 2$ вдихи $(n=3), 10$ вдихів $(n=4)$, 4-5 вдихів на годину $(n=1)$. Інструкції щодо продовження дихальних вправ після виписки значно відрізнялися (від 0 днів до 3 міс.).

Рекомендації щодо запобіжних заходів після стернотомії також надавалися кардіохірургічним пацієнтам [49]. Існували великі варіації цих інструкцій. Так, рекомендації щодо уникнення переносу ваги обмежувалися строком від 7 до 12 тиж. Обмеження ваги, котру можна підіймати, коливалось від 1 до 5 кг (медіана 2 кг, середня 2,5 кг). Впродовж періоду обмежень пацієнтам вводилися й інші заборони, котрі представлені у таблиці 1.

Окрім того, інструкції щодо зміни положень тіла (лежачи-сидячи-стоячи) надавали $90 \%$ фрізичних терапевтів за «стандартною методикою». Найчастішою технікою вставання 3 ліжка серед рекомендованих була така: лежачи на боці, поклавши одну чи обидві руки перед тілом, нахилитись вперед і відштовхнутися до сидячого положення.
Перед випискою з відділення кардіоторакальної хірургії всі опитані фрізичні терапевти Швеції надавали інформацію про фрізичні навантаження, вправи та реабілітацію, давали вказівки продовжувати вправи для верхніх кінцівок, проте час продовження програми тренувань коливався від 1 до 8 тиж.

Дослідження особливостей фрізичної терапії у клініках Греції було проведено C. Lomi та E. Westerdahl [28]. Усі фрізичні терапевти $(n=45)$ заявили, що вважають ФТ необхідною після КХВ; 69 \% вважали ФТ, котру надають, оптимальною. Брак ресурсів (персоналу), обладнання, спеціалізація/освіта та співпраця з лікарями були основними причинами неоптимальності ФТ. Письмові інструкції з ФТ, протоколи чи плани догляду були доступні для $11 \%$ респондентів.

У ході опитування фрізичних терапевтів у Греції [28] 53 \% респондентів відзначили, що передопераційне інфоормування проводилося усім пацієнтам. Воно частіше включало інформацію про дихальні вправи (64\%), техніки кашлю (58 \%), операцію (58 \%), ранню мобілізацію (29 \%), фрізичні вправи та профрілактику тромбозів (27 \%), запобіжні заходи після стернотомії (27 \%). Передопераційну ідентифікацію пацієнтів з високим ризиком післяопераційних ускладнень відмітили $29 \%$ фрізичних терапевтів.

345 опитаних фрізичних терапевтів [28] 41 мав досвід роботи у відділенні інтенсивної терапії: 29 відзначили, що ФТ у перший ПОД проводили усім пацієнтам, а 10 - лише за призначенням. Ніяких письмових вказівок чи протоколів щодо ФТ інтубованих пацієнтів не було у всіх респондентів. Дванадцять респондентів із 41, котрі працювали у відділенні інтенсивної терапії, виконували мануальну гіперінфрляцію та постукування на задній стороні грудної клітки.

Впродовж перших п'яти ПОД пацієнти, як правило, отримували від 1 до 6 процедур ФТ на день. 37 респондентів у Греції вказали, що фрізичний терапевт у їх лікарнях автоматично відвідував усіх пацієнтів після KXB, а 4 - за умови особливих потреб пацієнта. Сімдесят один відсоток фрізичних терапевтів повідомили, що протягом перших двох ПОД втручання ФТ регулярно проводили по суботах, а у неділю - відповідно 58 \%. Вечірню процедуру ФТ проводили в перший та другий ПОД за даними $38 \%$ респондентів з Греції [28].

Використання ранньої мобілізації та вправ фрізичними терапевтами Греції відрізнялося від даних, отриманих у Швеції. Зокрема виконання сидіння на краю ліжка чи на стільці під контролем фрізичного терапевта у перший ПОД відмітили $60 \%$ респондентів, а у другий та третій 
ПОД частота знизилася до 53 та 40 \%. У Греції щодо виконання стояння під контролем фрізичного терапевта частота і тенденція впродовж перших трьох ПОД були відрізнялися - 18, 64, $47 \%$. Ходьбу у палаті під контролем фрізичного терапевта здійснювали у 13, 44, 47 \% у перші три ПОД. Частота виконання ходьби у коридорі під контролем фрізичного терапевта також була нижчою - 7, 38, 51 \%. Білатеральні вправи для верхніх кінцівок виконували 27, 38 та $44 \%$ респондентів у перші три ПОД, а для нижніх кінцівок відповідно - 49, 67 та $64 \%$. Наявність групових тренувань відзначили чотири терапевти з Греції. Ходьбу сходами перед випискою проводили за даними $42 \%$ респондентів. Перед випискою інформацію про фрізичні навантаження, вправи та реабілітацію надавали пацієнтам згідно з даними $73 \%$ отриманих анкет [28].

Приблизно 90 \% фрізичних терапевтів Греції давали завдання пацієнтам регулярно виконувати дихальні вправи післяопераційно (найчастіше вправи з глибоким диханням - $82 \%$, стимулювальну спірометрію - $80 \%$ ), 1-4 рази на день впродовж перших двох ПОД. Кількість вдихів для одного тренування коливалась від одного до 40: 1-10 вдихів $(n=22), 11-30$ вдихів $(n=7), 40$ вдихів $(n=2)$. Позиціювання на боці лежачи використовували приблизно $50 \%$ респондентів. Інструкції щодо продовження дихальних вправ після виписки (від 3 днів до 6 міс.) надавали 38 фізичних терапевтів, 3 них 36 надали пацієнтам дихальний тренажер.

Рекомендації щодо запобіжних заходів після стернотомії також надавали кардіохірургічним пацієнтам у Греції. Інструкції щодо уникнення переносу ваги обмежували строком від 1 до 18 тиж. (в середньому 7). Обмеження ваги, котру можна підіймати, були аналогічними до результатів фрізичних терапевтів Швеції. Впродовж періоду обмежень пацієнтам вводили й інші заборони, котрі представлені у таблиці 1. Найчастішими техніками вставання з ліжка серед рекомендованих у Греції були: поворот на бік чи переміщення ніг з ліжка з подальшим нахиленням вперед до положення сидячи.

Дослідження особливостей ФТ після аортокоронарного шунтування у клініках Великої Британії було виконано J. Reeve та S. Ewan [34]. В опитуванні взяли участь сорок фрізичних терапевтів.

Щодо організації системи ФТ у лікарнях Великої Британії відзначалося, що 97,5 \% респондентів пропонували цілодобову ФТ «за дзвінком», $7,5 \%$ повідомили про наявність розширеного режиму з 8 ранку до 20 вечора; лише 2,5 \% не мали 24-годинного покриття.

Про наявність передопераційного візиту фрізичного терапевта до усіх пацієнтів повідомили
$57,5 \%$ респондентів (основними причинами для візиту були оцінка дихальної системи $(82,5 \%)$ та навчання дихальним маневрам (75 \%)); $35 \%$ респондентів відвідували лише деяких пацієнтів (основна причина - оцінка ризику). У тих випадках, коли фрізичний терапевт не відвідував паці$\epsilon н т а$, оцінку виконували за допомогою медичних карт, інфрормування іншими способами, з використанням відео чи друкованого матеріалу. Єдиним обстеженням, котре виконував лише фрізичний терапевт, була оцінка діапазону руху плечей, шийного та грудного відділів хребта. Усі інші оцінки були відтворені щонайменше ще одним членом багатопрофрільної команди. Окрім того, J. Reeve та S. Ewan [34] встановили, що основи та причини передопераційної та післяопераційної ФТ відрізняються.

Більшість опитаних у Великій Британії респондентів (80 \%) не відвідували інтубованих пацієнтів безпосередньо після операції; інші 20 \% відвідували для оцінювання, профрілактичного втручання та консультації (в основі цього був особистий досвід $(n=7)$, рекомендації з літературних джерел та усталена практика). Відсутність специфічних протоколів для ФТ у цей період переважала $(72,5 \%)$. У післяопераційний період візити фрізичного терапевта до усіх пацієнтів виконували $95 \%$ респондентів (з метою оцінювання, а $55 \%$ також для терапії у фрормі мобілізації та терапевтичних вправ, дихальних технік та стимулювання кашлю, позиціонування). Сестринський персонал широко використовувався для мобілізації пацієнтів $(37,5 \%$ ). Інші сорери програм включали освіту та поради щодо серцевої реабілітації.

Більша половина $(57,5 \%)$ респондентів відвідували пацієнтів п'ять і більше ПОД, досить велика частка впродовж чотирьох ПОД. У перший та другий ПОД частіше виконувалося два візити, а у третій та четвертий - один раз на день. У приватних лікарнях пролонгована тривалість ведення пацієнтів фрізичними терапевтами була частішою. Єдиний респондент, який повідомив, що не відвідує всіх пацієнтів післяопераційно, обгрунтував це рішення, виходячи з рекомендацій літературних джерел та з особистого досвіду (пацієнтам призначали вправи з глибоким диханням, техніки кашлю та мобілізацію медперсоналом у перший день згідно з чинними рекомендаціями літературних джерел [34].

Дослідження особливостей ФТ у 18 кардіохірургічних клініках Канади було виконано T. J. Overend зі співавт. [30]. Дослідники відзначили, що у 14 клініках був протокол догляду за пацієнтами, а 12 клінік мали специфічну інструкцію/протокол з ФТ. 
У ході опитування [30] $39 \%$ респондентів зазначили, що передопераційний візит фрізичного терапевта проводили усім пацієнтам. Оцінювання та терапію фрізичним терапевтом проводили у однаковій кількості у перший (89\%) та у другий ПОД (78\%), а у третій ПОД - 61 та $50 \%$ відповідно. Більша частина $(66,7 \%)$ респондентів відвідувала пацієнтів лише один раз у перший ПОД. Водночас у перший ПОД найпоширенішим втручанням були вправи з глибоким диханням та кашель (89 \%), стимулювальна спірометрія (44\%).

Оцінювання практики ФТ у Канаді [30] також дозволило визначити наявність великої різниці у мобілізації пацієнтів з причин недостатності персоналу, поглядів хірургів (наприклад, використання ходунків), практики догляду медичними сестрами. Особливості мобілізації у перший ПОД були такими: мобільність тільки у ліжку - $6 \%$ респондентів; сидіння на краю ліжка - $94 \%$; стояння - $11 \%$; пересаджування на стілець $50 \%$; ходьба у кімнаті - $22 \%$, у коридорі $6 \%$. У другий ПОД кількість типів мобілізації значно зменшувалася: ходьба у кімнаті - $17 \%$, у коридорі - $50 \%$, ходьба на довільну дистанцію - 33 \%. У третій ПОД виконували лише ходьбу у коридорі (39 \%) та на довільну відстань (61\%). Відповідальність за мобілізацію, як правило, розподілялася між фрізичними терапевтами та медсестрами; у 28 \% лікарень медсестри брали на себе головну роль, якщо не було проблем з мобільністю. Фізичні терапевти повідомили, що більше займаються складними пацієнтами.

Виконання та оцінка ходьби сходами (проводили фрізичні терапевти або медсестри) мала такі характеристики: $22 \%$ - для усіх пацієнтів; $33 \%$ - лише за наявності сходів у будинку пацієнта; 39 \% - якщо були проблеми з мобільністю (нова чи хронічна потреба у допомозі, десріцит рівноваги).
Фізичні терапевти Канади [30] повідомили, що у перший ПОД $72 \%$ респондентів оцінюють амплітуду рухів верхніми кінцівками, у другий лише $28 \%$. Вправи для верхніх кінцівок у перший ПОД використовували $44 \%$ респондентів, а у другий та третій - 55,5 \%. Поширеність використання вправ для нижніх кінцівок у перший та другий ПОД становила $67 \%$, а у третій - лише $22 \%$. Серед втручань легеневої ФТ найбільш поширеними у перший ПОД були глибоке дихання та кашель (89\%), стимулювальна спірометрія (44\%), а $67 \%$ фахівців забезпечували освіту щодо самолікування (дихальні вправи, кашель, терапевтичні вправи). Лише $50 \%$ респондентів продовжували надавати лікування на третій ПОД.

Рекомендації щодо запобіжних заходів після стернотомії також надавали кардіохірургічним пацієнтам у Канаді. 44 \% респондентів Канади [30] повідомили про повне обмеження двосторонніх вправ для плечових суглобів, а $17 \%$ - односторонніх. Обмеження відштовхування руками під час вставання відзначили 55,5 \% респондентів, а обмежену мобільність у ліжку у - $44 \%$. Максимальна вага для підняття становила 10 фрунтів у $83 \%$, а 5 фрунтів - у $17 \%$. Необхідність підтримання під час кашлю відзначали 89 \%. Один респондент не дозволяв використовувати жодну допомогу для ходьби, а три обмежували використання стандартних ходунків і дозволяли ходунки з колесами.

3 метою навчання пацієнтів елементам ФТ, у тому числі перед випискою, усі лікарні Канади використовували аудіовізуальні джерела інфоормації та теоретичні заняття з групами пацієнтів (мобілізація, ходьба, кардіореабілітація, вправи для кінцівок, запобіжні заходи після стернотомії, рекомендації щодо діяльності).

Враховуючи розглянуті особливості, можна констатувати наявність різних підходів до фрізичної терапії (табл. 2)

ТАБЛИЦЯ 2 - Особливості фізичної терапії після кардіохірургічних втручань у різних країнах

\begin{tabular}{|c|c|c|c|c|c|}
\hline Характеристика & $\begin{array}{c}\text { Австралія та Нова } \\
\text { Зеландія [44] }\end{array}$ & Швеція $[49,50]$ & Греція [28] & Велика Британія [34] & Канада [30] \\
\hline $\begin{array}{l}\text { Оцінювання/ } \\
\text { консультування } \\
\text { фізичним терапевтом } \\
\text { до операції }\end{array}$ & $\begin{array}{l}94 \text { \% лікарень } \\
\text { (оцінювання) }\end{array}$ & $\begin{array}{l}90 \text { \% лікарень } \\
\text { (консультування) }\end{array}$ & $\begin{array}{l}53 \text { \% лікарень } \\
\text { (консультування } \\
\text { та оцінювання) }\end{array}$ & $\begin{array}{l}57,5 \% \text { - візити } \\
\text { до усіх; } 35 \% \text { - } \\
\text { оцінювання }\end{array}$ & $\begin{array}{l}39 \text { \% лікарень } \\
\text { візити до усіх }\end{array}$ \\
\hline $\begin{array}{l}\text { Особливості } \\
\text { охоплення пацієнтів } \\
\text { після операції }\end{array}$ & $\begin{array}{l}89 \text { \% лікарень для усіх } \\
\text { пацієнтів }\end{array}$ & $\begin{array}{l}90 \text { \% лікарень для } \\
\text { усіх пацієнтів }\end{array}$ & \begin{tabular}{|l|}
82 \% лікарень \\
для усіх пацієнтів
\end{tabular} & $\begin{array}{l}95 \% \text { респондентів - } \\
\text { для усіх пацієнтів (3 } \\
\text { метою оцінювання, } \\
\text { а } 55 \text { \% - також для } \\
\text { терапії) }\end{array}$ & - \\
\hline Послуги у вихідні дні & 83 \% лікарень & \begin{tabular}{|l|} 
До $100 \%$ лікарень \\
у суботу, до 4,5 \% - \\
у неділю (перший \\
та другий ПОД)
\end{tabular} & $\begin{array}{l}71 \text { \% лікарень у } \\
\text { суботу, } 58 \text { \% - у } \\
\text { неділю (перший } \\
\text { та другий ПОД) }\end{array}$ & $\begin{array}{l}\text { 97,5 \% респондентів } \\
\text { пропонували } \\
\text { цілодобову ФТ «за } \\
\text { дзвінком» }\end{array}$ & - \\
\hline
\end{tabular}


Продовження таблиці 2

\begin{tabular}{|c|c|c|c|c|c|}
\hline Характеристика & $\begin{array}{c}\text { Австралія та Нова } \\
\text { Зеландія [44] }\end{array}$ & Швеція $[49,50]$ & Греція [28] & Велика Британія [34] & Канада [30] \\
\hline $\begin{array}{l}\text { Втручання чи } \\
\text { інструкції для } \\
\text { інтубованих пацієнтів } \\
\text { (безпосередньо після } \\
\text { операції) }\end{array}$ & Дані обмежені & $\begin{array}{l}\text { Наявні інструкції - } \\
13 \%\end{array}$ & $\begin{array}{l}\text { Не було у всіх } \\
\text { респондентів }\end{array}$ & $\begin{array}{l}80 \text { \% респондентів не } \\
\text { відвідували пацієнтів; } \\
20 \text { \% - оцінювання, } \\
\text { профрілактичне } \\
\text { втручання, } \\
\text { консультації }\end{array}$ & - \\
\hline $\begin{array}{l}\text { Протокол оцінки } \\
\text { фрізичним терапевтом } \\
\text { та/або протокол } \\
\text { лікування після } \\
\text { екстубації }\end{array}$ & $\begin{array}{l}76 \text { \%, але } 19 \text { \% } \\
\text { використовували лише } \\
\text { оцінювання пацієнта }\end{array}$ & $48 \%$ & - & - & - \\
\hline $\begin{array}{l}\text { Найбільш поширена } \\
\text { респіраторна фрізична } \\
\text { терапія }\end{array}$ & $\begin{array}{l}\text { Кашель, вправи з } \\
\text { глибоким диханням, } \\
\text { специфрічні вправи на } \\
\text { розширення грудної } \\
\text { клітки, уповільнені } \\
\text { глибокі вдихи (sustained } \\
\text { maximal inspiration) }\end{array}$ & $\begin{array}{l}\text { Кашель, вправи } \\
\text { з глибоким } \\
\text { диханням, } 3 \\
\text { позитивним тиском } \\
\text { на видиху }\end{array}$ & $\begin{array}{l}\text { Вправи з глибо- } \\
\text { ким диханням, } \\
\text { стимулююча } \\
\text { спірометрія, } \\
\text { діафрагмальні } \\
\text { вдихи, уповіль- } \\
\text { нені глибокі } \\
\text { вдихи } \\
\end{array}$ & $\begin{array}{l}\text { Кашель, вправи з } \\
\text { глибоким диханням, } \\
\text { техніка активних } \\
\text { циклів дихання, } \\
\text { уповільнені глибокі } \\
\text { вдихи }\end{array}$ & $\begin{array}{l}\text { Вправи з } \\
\text { глибоким } \\
\text { диханням } \\
\text { та кашель, } \\
\text { стимулювальна } \\
\text { спірометрія }\end{array}$ \\
\hline $\begin{array}{l}\text { Виконання вставання } \\
\text { та стояння / ходьби у } \\
\text { перший ПОД }\end{array}$ & - & 93/28 \% лікарень & 18/13 \% лікарень & - & $\begin{array}{l}11 / 22 \% \\
\text { лікарень }\end{array}$ \\
\hline $\begin{array}{l}\text { Ключові особливості } \\
\text { ранньої мобілізації }\end{array}$ & $\begin{array}{l}\text { Початок амбуляцій до } \\
\text { третьої доби вказаний } \\
\text { у } 75 \text { \% респондентів, } \\
\text { ходьба сходами на } \\
\text { четвертий-шостий Под } \\
\text { у } 83 \text { \% }\end{array}$ & Дивись текст & Дивись текст & - & Дивись текст \\
\hline
\end{tabular}

Примітка: ФТ - фрізична терапія; ПОД - післяопераційний день.

\section{Дискусія}

3 огляду на представлені результати можна зробити висновок, що загальним для фрізичної терапії кардіохірургічних пацієнтів $€$ використання ранньої мобілізації, терапевтичних вправ та легеневої/респіраторної фрізичної терапії впродовж перших ПОД. 3 іншої сторони, вибір вправ та тривалість лікування були різними серед фізичних терапевтів.

Ще у 1998 р. було зазначено, що фрізичні терапевти нехтують результатами досліджень і покладаються на особистий досвід [23]. Наукова література не $\epsilon$ основою для вибору підходу до фрізіотерапевтичного втручання [45]. Тому слід розглянути ключові характеристики практики ФТ кардіохірургічних пацієнтів з урахуванням результатів наукових досліджень.

Передопераційна консультація чи навчання пацієнта елементам ФТ давно вважається рутинним і важливим аспектом [4]. Їх важливість щодо одужання та відновлення легеневої фрункції зафріксована у літературних джерелах, проте немає досліджень, які б підтверджували ефеективність освітніх втручань фрізичного терапевта перед операцією на клінічно значимі критерії.
Водночас, розглянуті результати опитувань свідчать, що майже усі $[44,49]$ чи близько половини $[28,30,34]$ рецензентів використовують передопераційні візити/консультації/навчання 3 усіма пацієнтами. Проте, відповідно до сучасних даних, контакт віч-на-віч з усіма пацієнтами видається непотрібним, як і дублювання деяких передопераційних процедур оцінювання [34].

Традиційно вважається, що передопераційне оцінювання пацієнта фрізичним терапевтом зменшує тривожність і підвищує мотивацію, а отже, і післяопераційне співробітництво, що сприяє покращенню результатів [16, 20]. 3 іншої сторони, відсутні докази щодо його впливу на зміни вимог до знеболення, показників настрою пацієнтів, рухової активності та тривалості перебування у лікарні [34]. Обгрунтування передопераційних втручань залишається складним питанням, але оцінка пацієнтів з високим ризиком може бути фрактором відбору пацієнтів для передопераційної зустрічі з фрізичним терапевтом. Водночас, щодо фракторів, котрі фрізичні терапевти використовують для визначення пацієнтів з високим ризиком, також $\epsilon$ дискусії та заперечення деяких з них [44]. 
Потрібні подальші дослідження для встановлення ефективності передопераційних консультативних/навчальних втручань. При цьому слід враховувати, яка інфоормація і якими засобами, коли, кому і ким повинна бути надана [34].

Враховуючи роки публікування та проведення розглянутих опитувань фрізичних терапевтів можна спостерігати певну тенденцію до зменшення передопераційних візитів фрізичного терапевта. Проте залишається незрозумілим, що відображає ця тенденція, - лише практику в кожній країні чи зміни, котрі відбуваються з певних причин чи з причини впровадження результатів наукових досліджень у практику.

Щодо ФТ інтубованих пацієнтів після КХВ, то дані S. Potman зі співавт. [33] підтвердили відсутність її користі за відсутності ускладнень. Практика більшості респондентів у Великій Британії [34] відповідала цим висновкам, проте в Австралії та Новій Зеландії [44] 63 \% лікарень мали протокол ФТ для інтубованих пацієнтів, а у більшості респондентів зі Швеції протоколи для інтубованих пацієнтів були відсутніми [50].

Досить давно встановлено, що профілактична ФТ грудної клітки мало впливає на профрілактику післяопераційних легеневих ускладнень (ПЛУ) [9, $25,26,41]$. Більш сучасні роботи також підтвердили цей фракт [2, 10, 32]. Зокрема S. C. Jenkins зі співавт. [24] зроблено висновок, що додавання дихальних вправ або стимулювальної спірометрії до ранньої мобілізації та кашлю не приносить користі після неускладненої операції. У роботі P. A. Brasher [2] не було встановлено впливу вправ з глибоким диханням на тривалість госпіталізації, частоту ПлУ та легеневу функцію (у третій ПОД зниження становило близько $50 \%$ початкових результатів форсованої життєвої ємності легенів).

Систематичний огляд P. Pasquina зі співавт. [32] результатів профрілактичної респіраторної ФТ після КХВ встановив недоведеність ії̈ корисності. У дослідженні K. Stiller зі співавт. [40] повідомлено, що пацієнти, які не отримували передопераційної або післяопераційної респіраторної ФТ, не відрізнялися за ПлУ, а також запропоновано переглянути необхідність проведення профрілактичної ФТ грудної клітки після КХВ.

Незважаючи на таку велику кількість досліджень та їх результати, більшість фрізичних терапевтів рутинно оцінюють пацієнтів і застосовують програми втручань впродовж чотирьох-шести ПОД з метою профрілактики [34].

Стимулювальна спірометрія та вправи з глибоким диханням були найбільш розповсюджені серед підходів респондентів до респіраторної
ФТ кардіохірургічних пацієнтів. Водночас додавання вправ з глибоким диханням, стимулювальної спірометрії до протоколу ранньої мобілізації не впливає на відновлення легеневої фрункції та ПлУ [11, 25].

Незважаючи на відсутність доказів щодо переваг стимулюючої спірометрії кардіохірургічних пацієнтів $[29,32]$ це втручання було досить популярним серед фрізичних терапевтів Греції (80 \%) [28], Австралії та Нової Зеландії (63 \%) [44], Канади (50 \%) [30], Великої Британії (33\%) [34] та Швеції (17\%) [30]. Інші опитування щодо специфрічного використання стимулювальної спірометрії у Великій Британії показали коефіцієнти використання $44 \%$ у 1986 р. [21] та $71 \%$ - у 1998 р. [46]. Використання вправ з глибоким диханням було не менш поширеним серед фрізичних терапевтів Греції (82 \%) [28], Австралії та Нової Зеландії (97 \%) [44], Канади (89 \%) [30], Великої Британії (65 \%) [34] та Швеції (62\%) [30].

Використання дихальних вправ 3 пристроєм, котрий створює позитивний тиск на видиху, широко застосовується в клінічній практиці в Швеції [50], не зважаючи на відсутність доказів клінічної користі порівняно зі звичайними вправами на глибоке дихання [48].

Наразі немає достатньо доказів, які б підтверджували переваги однієї дихальної техніки над іншою [28]. Відсутні наукові докази щодо найбільш оптимальної частоти виконання дихальних вправ.

Щодо позиціювання пацієнтів, зокрема на боку, відомі позитивні ефеекти на об'єм легенів [22] та оксигенацію [19]. Окрім того, у дослідженні М. Chulay зі співавт. [7] відзначено можливість зниження післяопераційної захворюваності під час позиціювання пацієнтів на боку.

Поширеність використання позиціювання фізичними терапевтами була такою: Греція - $49 \%$ [28], Австралія та Нова Зеландя - 97 \% [44], Велика Британія - 93 \% [34], Швеція - 28 \% [30].

Наприкінці 1960-х років пацієнти принаймні 3 тиж. проводили в ліжку, відновлюючись після КХВ. 3 того часу практика післяопераційної фрізіотерапії змінилася у відповідь на досягнення медичних та хірургічних знань [49]. У розглянутих опитуваннях фрізичних терапевтів визначалися середні чи протокольні характеристики мобілізації «щоденного» пацієнта. Незважаючи на часте використання ранньої мобілізації, ії̈ користь для запобігання післяопераційних ускладнень не вивчена достатньо.

Систематичний огляд P.M.R. Santos зі співавт. [36] підтвердив різноманітність методик та періодів мобілізації, котрі зазначаються як ранні, а та- 
кож відсутність переваг між різними протоколами ранньої мобілізації, хоча групи ранньої мобілізації мали кращі результати порівняно з контрольними.

Відсутність клінічної значимості (показники тривалості госпіталізації, частота реадмісії до відділення інтенсивної терапії, пролежнів та тромбозів глибоких вен, легеневої емболії) від впровадження прогресивної мобілізації пацієнтів після КХВ у відділенні інтенсивної терапії встановлена S. Floyd зі співавт. [14].

У роботі Т. Castelino та співавт. [6] наголошено на тому, що якість та кількість досліджень ефективності ранньої мобілізації після КХВ $\epsilon$ недостатніми, а результати - суперечливими. У роботі R. Freeman та E. Koerner [15] також суперечливими $€$ дані щодо користі від включення засобів мобілізації у ранню ФТ після операції. Тривалість перебування у лікарні не змінилася й у рамках програми Покращене одужання після операції (Enhanced Recovery After Surgery, ERAS) $[5,13]$. Окрім того, дослідження впливу дихальних вправ, кашлю та допомоги під час мобілізації (ходьба з другого післяопераційного дня) встановило відсутність переваг щодо частоти післяопераційних легеневих ускладнень, гіпоксемії, результатів рентгенографрії та тривалості післяопераційного перебування порівняно з наданням лише вказівок про необхідність кашляти після операції і встати з ліжка на другий ПОД [10].

Досить великі відмінності у мобілізації паці$\epsilon$ нтів серед респондентів також підтверджують невизначеність терміну «рання мобілізація».

Завданнями пасивних, пасивно-активних та активних вправ для м'язів тулуба та плечового пояса, які часто $є$ частиною ФТ кардіохірургічних пацієнтів, є підтримка амплітуди рухів, запобігання постуральних змін та проблем із суглобами [27]. Проте ефрективність вправ для плечового пояса з підвищеною амплітудою руху $\epsilon$ не доказаною. Дослідження [37] показують, що такі вправи не зменшують післяопераційні обмеження у амплітуді рухів, котрі пов'язані з операцією.

3 іншої сторони, є дослідження [38], котре не встановило впливу терапевтичних вправ для м'язів плечового пояса та верхньої частини спини на показники болю та дисорункції плечового пояса та спини після КХВ (кістково-м'язові ускладнення розвинулися приблизно у 30 \% пацієнтів), що вказує на потребу додаткового з'ясування особливостей розвитку проблем з опорно-руховим апаратом після операції на серці для розробки більш ефективних засобів профрілактики та лікування.

Як було показано [28, 44, 49], вправи для нижніх кінцівок широко використовуються для запобігання ускладнень кровообігу, проте це за- вдання не підтверджено дослідженнями [12, 43]. Крім того, попередження утворення тромбів регулюється фармакологічними препаратами як до, так і після операції.

Оскільки використання ходьби сходами також варіювалося, слід відзначити, що при дотриманні відповідних клінічних критеріїв амбуляція та сходження по сходах після неускладненої операції не призводять до несприятливих клінічних наслідків [8].

Рекомендації щодо запобіжних заходів після стернотомії відрізнялися між фрахівцями та країнами, що може відображати відмінності між рекомендаціями хірургів та лікарняною політикою.

Наукові роботи свідчать про відсутність обгрунтувань традиційних обмежень пацієнтів після стернотомії [3]. Водночас, висловлено припущення, що поточні рекомендації щодо активності пацієнтів є занадто обмежуючими [31], а результати оцінки навантаження на груднину під час рухів верхніми кінцівками чи активності повсякденного життя підтвердили незначне навантаження під час виконання переважної більшості завдань [1, $17,42]$. У одному з досліджень автори закликали медичний персонал активізувати та мотивувати пацієнта для виконання побутових робіт та всіх видів фрізичних навантажень, оскільки це $є$ гарним прогнозом для продовження професійної роботи після операції [18].

Можна припустити, що співвідношення медсестра/пацієнт перевищує співвідношення фрізичний терапевт/пацієнт, і тому участь медсестер у виконанні певних завдань програми ФТ $є$ доцільною [44].

Водночас, велика кількість респондентів зазначила, що ФТ кардіохірургічних пацієнтів мають проводити професіонали високого рівня [34], що передбачає їх обізнаність у результатах досліджень, але основою для післяопераційної ФТ практики залишаються особисті уподобання або традиції закладу.

Викликає занепокоєння те, що уподобання хірургів чи анестезіологів займають більш високу позицію у формуванні практики ФТ, ніж дані літературних джерел. Незважаючи на усвідомлення результатів останніх досліджень респондентами, практика може залишатися без змін [34]. Інші дослідження вказують, що рекомендації хірурга, лікарняна політика та фрінансові обмеження мало впливають на вибір лікування [44]. Це говорить про те, що фрізичні терапевти можуть бути й не пов'язані з такими обмеженнями, а також мають незалежність у підборі лікування для окремих пацієнтів.

Таким чином у більшості кардіохірургічних лікарень ФТ пацієнтів може бути більш комплек- 
сною, ніж обгрунтованою результатами клінічних досліджень [41].

Особисті переваги мають найбільший вплив на вибір лікування, що може бути відображенням багаторічного досвіду більшості опитаних. Незважаючи на те, що респонденти вказували на те, що літературні джерела впливають на вибір лікування, це не завжди відображалось у відповідях.

3 огляду на результатів опитувань фрізичних терапевтів, дослідники наголошують, що необхідно зменшити чи видалити з практики ФТ недоцільні та неефективні втручання, забезпечити співвідношення ціни та якості, з метою найбільшої користі для здоров'я населення. Причин небажання змінювати практику ФТ $\epsilon$ складними. Особистісні фрактори середовища, поведінкові чинники, а також характер втручання, що потребує змін, впливатимуть на процес раціоналізації, модифрікації програм ФТ. Опублікування інформації зрідка $\epsilon$ достатньою причиною для зміни практики, і люди потребують багатьох речей впродовж процесу змін (визнання, просування по службі, інтерес та загальну безпеку).

Скасування чи спрощення програми ФТ має чимало потенційних наслідків, включаючи втрати чи перепрофрілювання персоналу, вплив на робочу культуру. Багато фрізичних терапевтів мають «практичний» підхід, і їм може бути важко зменшити обсяг втручань у більшості пацієнтів. Цільовими для фрізичних терапевтів можуть бути пацієнти з ускладненнями, зі зниженою мобільністю, мотивацією та обсягом рухової активності [34].

Отже, необхідний рівень та вид допомоги, що надаються фрізичними терапевтами пацієнтам, які перенесли кардіохірургічну операцію, потребують уточнення.

Хоча опитування в клінічній практиці не дають «доказів» у стандартному розумінні цього терміна, вони можуть бути корисними для опису

\section{Література}

1. Adams J, Pullum G, Stafford P, Hanners N, Hartman J, Strauss D, Hubbard M, Lawrence A, Anderson V, McCullough T: Challenging traditional activity limits after coronary artery bypass graft surgery: a simulated lawnmowing activity. J Cardiopulm Rehabil Prev. 2008;28:118-21.

2. Brasher PA, McClelland KH, Denehy L, Story I. Does removal of deep breathing exercises from a physiotherapy program including pre-operative education and early mobilization after cardiac surgery alter patient outcomes? Aust J Physiother. 2003;49:165-73.

3. Brocki BC, Thorup CB, Andreasen JJ. Precautions related to midline sternotomy in cardiac surgery: a review of mechanical stress factors leading to sternal complications. Eur J Cardiovasc Nurs. 2010;9:77-84.

4. Brooks-Brunn JA. Postoperative atelectasis and pneumonia. Heart \& lung. 1995; 24(2):94-115.

5. Brown JK, Singh K, Dumitru R, Chan E, Kim MP. The Benefits of Enhanced Recovery After Surgery Programs and Their Application in моделей практики. Також дослідження може допомогти фрізичним терапевтам України порівняти свою практику з практикою у інших країнах, а також проаналізувати ії обґрунтованість.

\section{Висновки.}

У ході дослідження було проведено аналіз сучасної практики фрізичної терапії пацієнтів після кардіохірургічних втручань у розвинутих країнах. Рутинне використання дихальних вправ, технік кашлю та мобілізації $€$ поширеним впродовж перших післяопераційних днів. Встановлено досить великі відмінності та різноманітність підходів до передопераційного консультування та навчання пацієнтів, використання фрізичної терапії для інтубованих пацієнтів, до мобілізації пацієнтів після операції, респіраторної фрізичної терапії, використання білатеральних та унілатеральних вправ для верхніх кінцівок, вправ для нижніх кінцівок. Кількість процедур також мала широкий діапазон. Рекомендації щодо запобіжних заходів після стернотомії відрізнялися як між фрахівцями однієї країни, так і між фрахівцями різних країн. Окрім того, терміни дотримання цих рекомендацій також різнилися. У кількох країнах фрізичну терапію пропонують регулярно усім пацієнтам після операцій на серці. Обгрунтованість ключових характеристик моделей практики фрізичної терапії залишається сумнівною. Особистий досвід, політика/ протокол лікарні та уподобання колег зазвичай слугують основою практики. Результати наукових досліджень важко впроваджуються у практику.

Перспективи подальших досліджень. Подальший аналіз та розробка міжнародних рекомендацій з науковим обгрунтуванням необхідні для встановлення оптимального протоколу фізичної терапії пацієнтів після хірургічних втручань на серці.

Конфлікт інтересів. Автори заявляють про відсутність конфрлікту інтересів.

Cardiothoracic Surgery. Methodist Debakey Cardiovasc J. 2018;14(2):77-88. doi:10.14797/mdcj-14-2-77

6. Castelino T, Fiore Jr JF, Niculiseanu P, Landry T, Augustin B, Feldman LS. The effect of early mobilization protocols on postoperative outcomes following abdominal and thoracic surgery: a systematic review. Surgery. 2016;159(4):991-1003. doi: 10.1016/j.surg.2015.11.029.

7. Chulay M, Brown J, Summer W: Effect of postoperative immobilization after coronary artery bypass surgery. Crit Care Med. 1982, 10: 176-9. doi:10.1097/00003246-198203000-00007.

8. Cockram J, Jenkins S, Clugston R: Cardiovascular and respiratory responses to early ambulation and star climbing following coronary artery surgery. Physiother Theory Pract. 1999; 15: 3-15. doi:10.1080/095939899307856.

9. Crowe JM, Bradley CA. The effectiveness of incentive spirometry with physical therapy for high-risk patients after coronary artery bypass surgery. Physical therapy. 1997;77(3): 260-8. 
10. de Charmoy SB, Eales CJ. The role of prophylactic chest physiotherapy after cardiac valvular surgery: is there one? S Afr J Physiother. 2000;56:24-8.

11. Dull JL, Dull WL. Are maximal inspiratory breathing exercises or incentive spirometry better than early mobilization after cardiopulmonary bypass? Physical Therapy. 1983; 63(5):655-9.

12. Flanc C, Kakkar VV, Clarke MB. Postoperative deep-vein thrombosis: Effect of intensive prophylaxis. The Lancet. 1969;293(7593): 477-9.

13. Fleming IO, Garratt C, Guha R, Desai J, Chaubey S, Wang Y, Leonard S, Kunst G. Aggregation of Marginal Gains in Cardiac Surgery: Feasibility of a Perioperative Care Bundle for Enhanced Recovery in Cardiac Surgical Patients. J Cardiothorac Vasc Anesth. 2016; 30 (3): 665-70. doi: 10.1053/j. jvca.2016.01.017

14. Floyd S, Craig SW, Topley D, Tullmann D. Evaluation of a progressive mobility protocol in postoperative cardiothoracic surgical patients. Dimensions of Critical Care Nursing. 2016;35(5):277-82.

15. Freeman R, Koerner E. Instituting a Standardized Mobility Aid in the Cardiovascular Intensive Care Unit. Critical care nursing quarterly. 2018;41(3):289-96

16. Frownfelter DL. Principles and practice of cardiopulmonary physical therapy, 2nd edn. St Louis: Mosby; 1987. 864p.

17. Ge W, Sfara A, Hians B. Sternal skin strain during shoulder movements and upper extremity activities. Physiotherapy. 2015;101:e449-e450.

18. Hallberg V, Kataja M, Tarkka M, Palomaki A: Retention of work capacity after coronary artery bypass grafting. A 10-year follow-up study. J Cardiothorac Surg. 2009;4(1): 6.

19. Hardie JA, Morkve O, Ellingsen I: Effect of body position on arterial oxygen tension in the elderly. Respiration. 2002; 69: 123-8.

20. Hough A. Physiotherapy in Respiratory Care: An evidence based approach to respiratory and cardiac management, 3rd edn. London: Chapman \& Hall; 1998. 550p.

21. Jenkins SC, Soutar AS. A survey into the use of incentive spirometry following coronary artery by-pass graft surgery. Physiotherapy. 1986;72:492-3.

22. Jenkins SC, Soutar SA: The effects of posture on lung volumes in normal subjects and in patients pre- and post-coronary artery surgery. Physiotherapy. 1988;74:492-6.

23. Jenkins $S$. Recent advances and future challenges in cardiopulmonary physiotherapy. Physiotherapy Theory and Practice. 1998;14(3):177-81.

24. Jenkins SC, Soutar SA, Loukota JM, Johnson LC, Moxham J. Physiotherapy after coronary artery surgery: are breathing exercises necessary? Thorax. 1989;44(8):634-9.

25. Jenkins SC, Soutar SA, Loukota JM, Johnson LC, \& Moxham J (1990). A comparison of breathing exercises, incentive spirometry and mobilisation after coronary artery surgery. Physiotherapy theory and practice, 6(3), 117-126.

26. Johnson D, Kelm C, To T, Hurst T, et al. Postoperative physical therapy after coronary artery bypass surgery. American journal of respiratory and critical care medicine. 1995; 152(3): 953-8.

27. Kieran M, McCoy P, Webber BA, Pryor JA. Surgical patients and patients requiring intensive care. In Webber BA and PryorJA(Eds): Physiotherapy for Respiratory and Cardiac Problems. Edinburgh: Churchill Livingstone; 1993. pp. 237-279.

28. Lomi C, Westerdahl E. Physical therapy treatment after cardiac surgery: a national survey of practice in Greece. J Clin Exp Cardiolog. 2013; $7(004): 1-5$.

29. Overend TJ, Anderson CM, Lucy SD, Bhatia C, Jonsson BI, Timmermans $C$. The effect of incentive spirometry on postoperative pulmonary complications: a systematic review. Chest. 2001;12:971-8. doi:10.1378/ chest.120.3.971.

30. Overend TJ, Anderson CM, Jackson J, Lucy SD, Prendergast M, Sinclair S. Physical therapy management for adult patients undergoing cardiac surgery: a Canadian practice survey. Physiotherapy Canada. 2010;62(3): 215-21.

vitomskiyvova@gmail.com
31. Parker R, Adams JL, Ogola G, McBrayer D, Hubbard JM, McCullough TL, Hartman JM, Cleveland T. Current activity guidelines for CABG patients are too restrictive: comparison of the forces exerted on the median sternotomy during a cough vs. lifting activities combined with valsalva maneuver. Thorac Cardiovasc Surg. 2008;56:190-4.

32. Pasquina $P$, Tramèr MR, Walder $B$. Prophylactic respiratory physiotherapy after cardiac surgery: systematic review. Brit Med J. 2003;327:1379-84. doi: 10.1136/bmj.327.7428.1379.

33. Potman S, Sanderson D, Blackmore M. Physiotherapy following cardiac surgery: is it necessary during the intubation period? Australian Journal of Physiotherapy. 2001;47(1):7-18.

34. Reeve J, Ewan S. The physiotherapy management of the coronary artery bypass graft patient: a survey of current practice throughout the United Kingdom. Assoc Chart Physiother Resp Care. 2006;27: 35-45.

35. Reeve J, Denehy L, Stiller K. The physiotherapy management of patients undergoing thoracic surgery: a survey of current practice in Australia and New Zealand. Physiotherapy Research International. 2007;12(2):59-71.

36. Santos PMR, Ricci NA, Suster ÉA, Paisani DM, Chiavegato LD Effects of early mobilisation in patients after cardiac surgery: a systematic review. Physiotherapy. 2017;103(1):1-12

37. Shaw DK, Deutsch DT, Bowling RJ: Efficacy of shoulder range of motion exercise in hospitalized patients after coronary artery bypass graft surgery. Heart \& Lung. 1989;18: 364-9.

38. Stiller K, Mclnnes M, Huff N, Hall B. Do exercises prevent musculoskeletal complications after cardiac surgery? Physiotherapy Theory and Practice. 1997;13:117-26.

39. Stiller K, Crawford R, McLnnes M, Montarello J, Hall B. The incidence of pulmonary complications in patients not receiving prophylactic chest physiotherapy after cardiac surgery. Physiotherapy Theory and Practice. 1995;11(4):205-8.

40. Stiller K, Montarello J, Wallace M, Daff M, et al. Are breathing and coughing exercises necessary after coronary artery surgery?.Physiotherapy Theory and Practice. 1994;10(3): 143-2.

41. Stiller K, Montarello J, Wallace M, Dajf M, et al. Efficacy of breathing and coughing exercises in the prevention of pulmonary complications after coronary artery surgery. Chest. 1994; 105(3): 741-7.

42. Swanson LB, LaPier TK. Upper Extremity Forces Generated During Activities of Daily Living: Implications for Patients Following Sternotomy. Journal of Acute Care Physical Therapy. 2014;5(2):70-6.

43. Tsapogas MJ, Goussous H, Peabody RA, Marmody AM, Eckert C. Postoperative venous thrombosis and the effectiveness of prophylatic measures. Archives of Surgery. 1971;103: 561-7.

44. Tucker B, Jenkins S, Davies K, McGann R, et al. The physiotherapy management of patients undergoing coronary artery surgery: a questionnaire survey. Australian Journal of Physiotherapy. 1996;42(2):129-7.

45. Turner PAT, Whitfield TA. Physiotherapists' use of evidence based practice: a crossnational study. Physiotherapy Research International. 1997;2(1):17-29.

46. Wattie J. Incentive spirometry following coronary artery bypass surgery. Physiotherapy. 1998;84:508-14. doi:10.1016/S0031-9406(05)65874-9.

47. Wattie J. Incentive spirometry following coronary artery bypass surgery. Physiotherapy. 1998;84(10):508-14.

48. Westerdahl E, Lindmark B, Eriksson T, Hedenstierna G, Tenling. A The immediate effects of deep breathing exercises on atelectasis and oxygenation after cardiac surgery. Scand Cardiovasc J. 2003;37:363-7.

49. Westerdahl E, Moller M. Physiotherapy-supervised mobilization and exercise following cardiac surgery: A national questionnaire survey in Sweden. J Cardiothorac Surg. 2010; 5: 67

50. Westerdahl E, Olsen MF. Chest physiotherapy and breathing exercises for cardiac surgery patients in Sweden-A national survey of practice. Monaldi Arch Chest Dis. 2011;75:112-9. 